The Catholic University of America, Columbus School of Law

CUA Law Scholarship Repository

1985

\title{
Another Way of Looking at School Aid
}

John H. Garvey

The Catholic University of America, Columbus School of Law

Follow this and additional works at: https://scholarship.law.edu/scholar

Part of the Constitutional Law Commons, and the Education Law Commons

\section{Recommended Citation}

John H. Garvey, Another Way of Looking at School Aid, 1985 SUP. CT. REV. 61.

This Article is brought to you for free and open access by the Faculty Scholarship at CUA Law Scholarship Repository. It has been accepted for inclusion in Scholarly Articles and Other Contributions by an authorized administrator of CUA Law Scholarship Repository. For more information, please contact edinger@law.edu. 


\section{ANOTHER WAY OF LOOKING}

\section{AT SCHOOL AID}

In the 1983 and 1984 Terms the Supreme Court decided several controversial cases about government aid to schools. In 1984 it held in Grove City College v. Bell ${ }^{1}$ that scholarship aid to college students counted as assistance to the school for purposes of Title $\mathrm{IX}^{2}$ but that only the school's financial aid program had to comply with that law. Last Term the Court held that remedial and other aid for parochial school students counted as assistance to their schools and that the aid programs were altogether invalid under the Establishment Clause. Though both events caused quite a stir, ${ }^{3}$ no one seems to have noticed that the problems were virtually identical. The solutions were not, though I think they should have been.

Grove City involved a small private school that refused as a matter of principle to accept federal or state aid. It did, however, admit students who paid their tuition with congressionally authorized Pell grants. ${ }^{4}$ The Court held that that money was indirect aid to the school and that the school was therefore required to abide by the

John H. Garvey is Visiting Professor of Law, University of Michigan Law School.

ACTHOR'S NoTE: I would like to thank Alex Aleinikoff, Paul Bator, and Fred Schauer for reading an earlier version of this paper. While on leave in the Office of the Solicitor General, I participated in briefs in Grove City and in Mueller v. Allen; the views expressed here are my own.

${ }^{1} 104$ S.Ct. 1211 (1984).

2 Education Amendments of 1972, 20 U.S.C. $\$ 1681$ et seq. (1982).

${ }^{3}$ Congress is considering several bills designed to overturn Grove City. H.R. 700, 99th Cong., 1st Sess. (1985); S. 272, 99th Cong., Ist Sess. (1985); S. 431, 99th Cong., 1st Sess. (1985).

+20 U.S.C. $\S 1070(\mathrm{a})$ (1982).

(C) 1986 by The University of Chicago. All rights reserved.

$0-226-46438-5 / 86 / 1985-0091 \$ 01.00$ 
prohibition against sex discrimination in Title IX. But Title IX only applies to the "education program or activity receiving Federal financial assistance," not to the recipient institution as a whole. The Court found that in the case of Pell grants the only program covered by the antidiscrimination principle was the school's financial aid program.

Last Term's cases were Grand Rapids School District v. Ball ${ }^{6}$ and Aguilar v. Felton. ${ }^{7}$ In Grand Rapids the school district offered two programs in the parochial schools. One (Shared Time) provided remedial and "enrichment" math and reading, art, music, and physical education. These were taught during regular class periods by full-time public school employees, in rooms "leased" (at $\$ 6.00$ per room per week) from the parochial schools, with materials supplied by the public school system. The other (Community Education) offered such courses as arts and crafts and chess in voluntary classes at the end of the school day. These were taught in large part by instructors already teaching at the schools where the courses were offered. No attempt was made to monitor either program for religious content. ${ }^{8}$

The Court held both programs unconstitutional under the Lemon antiestablishment test ${ }^{9}$ because they had the effect of advancing religion. This effect, the Court said, might occur in three ways. First, the teachers might "become involved in intentionally or inadvertently inculcating particular religious tenets or beliefs." 10 There was no evidence that this had happened, but the Court found evidence unnecessary since the classes weren't monitored and no one had any incentive to report violations. Second, the programs might subsidize the schools' religious function by providing "direct aid to [their] educational function." 11 Third, "the programs may provide a crucial symbolic link between government and religion[.]"12

s 20 U.S.C. $\$ 1681(\mathrm{a})$ (1982).

6105 S.Ct. $3216(1985)$.

7105 S.Ct. 3232 (1985).

8 105 S.Ct. at 3218-20.

9 See Lemon v. Kurtzman, 403 U.S. 602, 612-13 (1971).

${ }^{10} 105$ S.Ct. at 3223.

${ }^{11}$ Id. at 3229.

${ }^{12}$ Id. at 3223. The Chief Justice and Justice O'Connor each concurred in the judgment as to the Community Education program but dissented as to the Shared Time program. Id. at 3231. Justices White (id. at 3249) and Rehnquist (id. at 3231) would have upheld the constitutionality of both programs. 
In Aguilar the Court struck down New York City's program for using Title I money ${ }^{13}$ to provide remedial reading and math, English as a second language, and guidance services to parochial school students at their own schools. The offerings were staffed by regular public school employees and monitored by field personnel and program coordinators.

New York City's program was thus similar to the Shared Time program in Grand Rapids, but the issue was different because New York had monitored its classes for religious content and found no improper effects. Catch-22. New York's monitoring violated the entanglement part of the Lemon test. Having government agents work with parochial school personnel on matters like schedules and students' needs posed a danger for nonadherents of the school's denomination. ${ }^{14}$ Having them "guard against the infiltration of religious thought"15 threatened the religious liberty of those at the school.

\section{ANTIESTABLISHMENT AND ANTIDISCRIMINATION}

\section{A. THE ANTIESTABLISHMENT PRINCIPLE}

I begin by pointing out the similarity in structure and function of the antiestablishment principle applied in Grand Rapids and Aguilar and the antidiscrimination principle applied in Grove City. The antiestablishment principle in parochial school aid cases is really a "state action" rule written in substantive First Amendment terms. In the typical state action case a private institution (a school, ${ }^{16}$ a hospital, ${ }^{17}$ a nursing home, ${ }^{18}$ a restaurant ${ }^{19}$ ) has done something

${ }^{13}$ Title I of the Elementary and Secondary Education Act of 1965, as amended, Pub. L. No. 96-561, 92 Stat. 2153 (1978), authorized the Secretary of Education to distribute money to local educational agencies to meet the needs of educationally deprived children from lowincome families. (It has been superseded by Chapter I of the Education Consolidation and Improvement Act of 1981, 20 U.S.C. $\$ 3801$ et seq. (1982), but the relevant provisions are virtually identical.) The statute gives local educational agencies some freedom to design programs (\$3805(a)), but they must include services for deprived children in private schools (§ 3806(a)).

${ }^{1+} 105$ S.Ct. at 3237.

${ }^{15}$ Id. at 3239.

${ }^{16}$ Rendell-Baker v. Kohn, 457 U.S. 830 (1982).

${ }^{17}$ Simkins v. Moses H. Cone Memorial HospitaI, 323 F.2d 959 (4th Cir. 1963), cert. denied, 376 U.S. 938 (1964).

${ }^{18}$ Blum v. Yaretsky, 457 U.S. 991 (1982).

${ }^{19}$ Burton v. Wilmingron Parking Authority, 365 U.S. 715 (1961). 
(discriminated, interfered with speech, denied a hearing) that the Constitution forbids government to do. The plaintiff will claim that the institution's behavior should be considered "state action" because the government has given the institution a lot of money or otherwise significantly involved itself in the institution's affairs.

In cases where the plaintiff is successful it doesn't really matter whether the government intended that the institution should misbehave. ${ }^{20}$ But the plaintiff does have to show that the government is "responsible"21 in the sense that there is some causal nexus between what it has done and the specific institutional activity complained of.

In parochial school aid cases private institutions are engaged in behavior (religious activity) that the Constitution forbids to government. There is nothing wrong with such activity if it remains private-indeed it is then protected by the Free Exercise Clause. But Lemon $v$. Kurtzman says that the government may not purposefully promote such activity nor take action whose principal or primary effect is to do so. Lemon also says (though this is really just another kind of effect) that the government "must not foster 'an excessive government entanglement with religion.' "22

\section{B. THE ANTIDISCRIMINATION PRINCIPLE}

The antidiscrimination principle in Title IX is also a "state action" rule, though one that is broader than the Constitution alone would require. Title IX says that ${ }^{23}$

No person in the United States shall, on the basis of sex, be excluded from participation in, be denied the benefits of, or be subjected to discrimination under any education program or activity receiving Federal financial assistance[.]

If discrimination occurs, the granting agency must see that it is eradicated. If it is not, the agency is authorized to cut off assistance

\footnotetext{
${ }^{20}$ When the plaintiff accuses the government itself of discrimination, he or she usually has to show such an improper intent. Personnel Administrator of Mass. v. Feeney, $4+2$ U.S. 256, 279 (1979); Washington v. Davis, 426 U.S. 229, 239-44 (1976). The Court hasn't altogether squared this comparatively recent rule with more ancient state action principles. See Choper, Thoughts on State Action: The "Government Function" and "Power Theory" Approaches, 1979 Wash. U.L.Q. 757, 765-69.
}

${ }^{21}$ Blum v. Yaretsky, note 18 supra, 457 U.S. at 1011.

22403 U.S. at 612-13 (emphasis added).

${ }^{23} 20$ U.S.C. $\$ 1681$ (a) (1982). 
"to the particular program, or part thereof, in which" discrimination is occurring. ${ }^{24}$

As the cutoff sanction shows, Title IX's objective is not to forbid discrimination by private or other nonfederal institutions outright but to assure that the federal government does not support it either on purpose or in effect. The statute deems the government responsible, regardless of its intent, for any discrimination that occurs in an "education program or activity receiving Federal financial assistance." To say that the government is deemed to support discrimination is really to say that it is thought to "cause" discriminatory "effects" under these circumstances. Other statutes apply the same principle to discrimination based on race (Title VI of the 1964 Civil Rights Act), ${ }^{25}$ physical handicap ( $\$ 504$ of the Rehabilitation Act), ${ }^{26}$ and age (the Age Discrimination Act). ${ }^{27}$

It should not be surprising that the antiestablishment and antidiscrimination principles look so similar. Both are designed to assure that the government does not get involved in constitutionally forbidden activity when it gives aid to private educational institutions. Both began as principles of constitutional law ("state action"), though the constitutional antidiscrimination rules have been largely displaced by statute, beginning with the 1964 Civil Rights Act. It is only because the statutory rules are the effective ones (and because they are so well developed through regulations and case law) that I am not comparing what are really companion constitutional doctrines.

\section{CAUSES AND EFFECTS}

Here I propose to consider the Court's concern with "effects" in school aid cases. ${ }^{28}$ In Title IX law the presumption that government has caused improper effects is limited in three ways: (1) it only applies if there is "Federal financial assistance"; (2) it only applies to the actions of "recipients" (i.e. those who are "receiving"

\footnotetext{
${ }^{2+} 20$ U.S.C. $\S 1682(1982)$.

${ }^{25} 42$ U.S.C. $\S 2000$ (d) et seq. (1982).

${ }^{26} 29$ U.S.C. \& 794 (1982).

2742 U.S.C. $\$ 6101$ et seq. (1982).

${ }^{28}$ For reasons I will relate below, the "purpose" prong of the Lemon and antidiscrimination rules has been irrelevant in these cases. See pages 73-74 infra.
} 
assistance); and (3) in the case of any recipient, it only applies if the discrimination occurs in the particular "program or activity" to which federal aid is going. The development of these Title IX rules offers a sense of organization and direction that has been missing in First Amendment cases. Yet the very same rules are being applied, when government "causes" religious "effects" by giving aid to educational institutions. ${ }^{29}$ The only difference concerns factor (3) (the "program or activity" rule). In applying that rule the Court has been much more willing to find institution-wide effects in Establishment Clause cases. The statutory rules thus provide a useful standard for judging where parochial school aid cases have taken a wrong turn.

\section{A. PRELUDE}

Before I take up the effects rules, it may be useful to provide a list of things they permit (col. A) and forbid (col. B) government to provide to parochial schools (see table 1). Then I can try to explain how this division came about.

Though there are family resemblances within each column, there are distressing conflicts when they are laid side-by-side. A review of comparable problems under the antidiscrimination principle may make the results seem at least coherent, if not correct.

\section{B. WHAT IS "FINANCIAL ASSISTANCE"?}

As the term "financial assistance" suggests, the nondiscrimination principle only applies where the government gives educational institutions something of value for nothing. The same is true in Establishment Clause cases. Such assistance may cause forbidden effects in a number of ways: it may provide new opportunities for the institution to work "harm" (discrimination or indoctrination); it may also suggest government approval of the harmful enterprise. I will take up later the precise ways in which these effects are thought to be caused. They do not always occur when financial

\footnotetext{
${ }^{29}$ Coverage is the only question that occurs in parochial school aid cases. There is no question but that the schools are engaged in religious activity. In antidiscrimination cases, by contrast, there are difficult questions about whether the institutional conduct that the government may be assisting counts as "discrimination" for statutory purposes. See, e.g., Guardians Assn. v. Civil Service Comm'n, N.Y.C., 463 U.S. 582 (1983); Alexander v. Choate, 105 S.Ct. 712, 716-20 (1985).
} 
TABLE 1

\begin{tabular}{|c|c|}
\hline$A$ & B \\
\hline \multicolumn{2}{|l|}{ Property tax exemptions ${ }^{30}$} \\
\hline Tax deductions for parents ${ }^{31}$ & Tax credits for parents ${ }^{4+}$ \\
\hline Scholarships (college) ${ }^{32}$ & Tuition grants (lower schools) ${ }^{45}$ \\
\hline Lunches ${ }^{33}$ & $\ldots$ \\
\hline Books ${ }^{34}$ & Other materials ${ }^{46}$ \\
\hline Statc-prepared tests ${ }^{35}$ & Teacher-prepared tests ${ }^{47}$ \\
\hline $\begin{array}{l}\text { Reimbursement for state-prepared tests } \\
\text { and record keeping }{ }^{36}\end{array}$ & $\ldots$ \\
\hline Diagnostic services ${ }^{37}$ & \\
\hline Bus rides to school ${ }^{38}$ & Bus rides on field trips ${ }^{48}$ \\
\hline Therapeutic services off premises ${ }^{30}$ & Therapeutic services on premises ${ }^{49}$ \\
\hline $\begin{array}{l}\text { Counscling off premises; }{ }^{+0} \text { remedial } \\
\text { instruction off premises }{ }^{+1}\end{array}$ & $\begin{array}{l}\text { Counseling on premises; } i^{50} \text { remedial, } \\
\text { accelerated, or supplemental instruction } \\
\text { on premises }\end{array}$ \\
\hline Construction grants (college) ${ }^{42}$ & $\begin{array}{l}\text { Maintenance and repair grants (lower } \\
\text { schools) }^{52}\end{array}$ \\
\hline Noncategorical grants (college) ${ }^{43}$ & Teachers' salaries ${ }^{53}$ \\
\hline
\end{tabular}

${ }^{30}$ Sec Walz v. Tax Commission, 397 U.S. 664 (1970).

${ }^{31}$. Mueller v. Allen, 463 U.S. 388 (1983).

32 Americans United for Separation of Church and State v. Blanton, 433 F. Supp. 97 (M.D. Tenn.), aff'd, 434 U.S. 803 (1977); Smith v. Bd. of Governors of University of N.C., 429 F. Supp. 871 (W.D.N.C.), aff'd, 434 U.S. 803 (1977). Cf. Witters v. Wash. Dept. of Services for the Blind, 54 USLW 4135 (Jan. 27, 1986).

${ }^{33}$ See Lemon, note 9 supra, 403 U.S. at 616.

${ }^{34}$ Board of Education v. Allen, 392 U.S. 236 (1968).

35 Wolman v. Walter, 433 U.S. 229 (1977).

${ }^{36}$ Committee for Public Education v. Regan, 444 U.S. 646 (1980).

37 Wolman, note 35 supra.

${ }^{38}$ Everson v. Board of Education, 330 U.S. 1 (1947).

${ }^{39}$ Wolman, note 35 supra.

+o Ibid.

+1 lbid.

42 Tilton v. Richardson, 403 U.S. 672 (1971); ff. Hunt v. McNair, 413 U.S. 734 (1973).

43 Roemer v. Maryland Public Works Bd., 426 U.S. 736 (1976).

* Committee for Public Education v. Nyquist, 413 U.S. 756 (1973).

${ }^{45}$ Nyquist, note 4 supra; Sloan v. Lemon, 413 U.S. 825 (1973).

+6 Wolman, note 35 supra; Meek v. Pittenger, 421 U.S. 349 (1975) (given to school).

47 Levitt v. Committee for Public Cducation, 413 U.S. 472 (1973).

48 Wolman, note 35 supra.

49. Meek, note 46 supra.

so lbid.

${ }^{51}$ Grand Rapids, note 6 supra; Aguilar, note 7 supra; Meek, note 46 supra. Cf. Public Funds for Public Schools of N.J. v. Marburger, 358 F. Supp. 29 (D.N.J. 1973), aff'd, 417 U.S. 961 (1974) (grants ot nonpublic schools to be used for hiring public school personnel for remedial services).

$\$ 2$ Nyquist, note 44 supra. 
assistance is given to an institution; ${ }^{54}$ but that is a necessary condition, if not a sufficient one.

1. Grants. The paradigm of "financial assistance" under both principles is the outright grant or loan of money to a school. ${ }^{55}$ And there is no real difference between a grant of cash and a gift of property ${ }^{56}$ or, as in Grand Rapids and Aguilar, services. ${ }^{57}$ All are cases where the institution gets something for nothing. All may provide new opportunities for discrimination or indoctrination. ${ }^{58}$ All may involve a suggestion of government approval. "Why else," one may ask, "would the government bestow favors on the institution?"

2. Procurement. Dealing with the "leases" of classrooms in Grand Rapids is a trickier matter, and perhaps for that reason the Court ignored the issue. The arrangement is like the Pennsylvania law held invalid in Lemon, which authorized the state Superintendent of Public Instruction "to 'purchase' specified 'secular educational services' from nonpublic schools." 259 What's going on in both cases is an attempt to build on the intuition-made explicit in antidiscrimination cases-that government procurement contracts do not count as "financial assistance." The reason is that the purchase ${ }^{60}$ or

${ }^{53}$ Lemon, note 9 supra.

5. A state may give cash to a religious college without violating the Establishment Clause. See col. A at notes 42 and 43 .

${ }^{55}$ Compare 34 C.F.R. $\$ 106.2(\mathrm{~g})(1)$ (1984) (Department of Education Title IX regulation) with Nyquist, 413 U.S. at 762 (maintenance and repair grants to nonpublic elementary and secondary schools). Whether the grant violates the antidiscrimination or antiestablisliment rule is a different question. All three coverage questions-including the "program or activity" rule-must be satisfied before one can reach that conclusion.

${ }^{56}$ See 34 C.F.R. \$ 106.2(g)(2) (1984) ("A grant of Federal real or personal property . . . , including surplus property"). Plaintiffs challenging federal assistance of this type will have difficulty in Cstablishment Clause cases after Valley Forge College v. Americans United, 454 U.S. 464 (1982), which denied standing because the donation of surplus property was not an exercise of the spending power. That problem will ordinarily not afflict those challenging state aid.

${ }^{57}$ Cf. 34 C.F.R. § 106.2(g)(3) (1984).

${ }^{58}$ As Grand Rapids and Aguilar show, it may be harder to pervert services provided in kind to religious or discriminatory ends.

59403 U.S. at 609 . See also the schemes for "reimbursing" schools for giving and grading tests that the Court dealt with in Levitt and Regan, notes 36, 47 supra. The Court in Lemon never actually decided whether this form of aid had the effect of promoting religion. Instead, it said that the effort to find out would entail impermissible entanglement. 403 U.S. at 61125.

${ }^{60}$ Randolph v. Alabama Inst. for Deaf and Blind, 27 Fair Empl. Prac. Cas. (BNA) 1718 (N.D. Ala. 1982) (\$ 504). 
rental $^{61}$ of services or goods at fair market value for the government's own account does not cause forbidden effects because it does not subsidize or suggest approval of the contractor's behavior.

There are a few flaws in the analogy. If the services provided in Lemon were not, say, 1,000 hours of secular education but 900 hours mixed with 100 of religious indoctrination, then the government would get no value for part of its dollar and would to that extent be giving the school something for nothing. ${ }^{62}$ More important, the government is not really buying for its own account in these cases. Paying for the rooms (Grand Rapids) and providing "secular educational services" (Lemon) are things the parochial schools would do for their students anyway. So the government really is giving them something for nothing-no change of behavior on their part. ${ }^{63}$

3. Tax benefits. A third type of "financial assistance" problem is the treatment of tax benefits. It now seems undisputed that tax exemptions do not subject institutions to the requirements of Title IX and its cognate statutes. ${ }^{64}$ The statutory language is fairly clear. ${ }^{65}$ Anyway, treating exemptions as subsidies assumes that some ideal share of everyone's property and earnings already belongs to the government, which can hand out money by either (i) releasing its claim or (ii) collecting on its claim and then giving the money back. ${ }^{66}$ In deciding what should count as getting some-

${ }^{61}$ Cook v. Budget Rent-A-Car Corp., 502 F. Supp. 494 (S.D.N.Y. 1980) (\$ 504); 28 C.F.R. $\$ 41.3(\mathrm{c})$ (1984) ("any grant, loan, contract (other than a procurement contract ... )") (Department of Justice $\$ 504$ regulation).

${ }^{62}$ Cf. Bernard B. v. Blue Cross and Blue Shield, 528 F. Supp. 125, 132 (S.D.N.Y. 1981), aff'd, 679 F.2d 7 (2d Cir. 1982).

${ }^{63}$ See New York v. Cathedral Academy, 434 U.S. 125, 134 (1977). A better Establishment Clause analogy might be an Army base buying bread or brandy from local Benedictine monks. Or maybe even Bradfield v. Roberts, 175 U.S. 291, 294 (1899).

it Paralyzed Veterans of America v. CAB, 752 F.2d 694, 709-710 (D.C. Cir. 1985), cert. granted, No. 85-289 (Oct. 21, 1985); Bachman v. American Society of Clinical Pathologists, 577 F. Supp. 1257, 1263-65 (D.N.J. 1983). McGlotten v. Connally, 338 F. Supp. 448, 460-62 (D.D.C. 1972), held that some tax exemptions were tantamount to "Federal tinancial assistance" for purposes of Title VI. The case was roundly criticized in Bittker \& Kaufman, Taxes and Civil Rights: "Constitutionalizing" the Internal Revenue Code, 82 Yale L.J. 51 (1972), and has not been followed since.

os 20 U.S.C. $\$ 1682$ (1982) equates "Federal financial assistance" with "grant, loan, or contract other than a contract of insurance or guaranty." See also 42 U.S.C. $\$ 2000 \mathrm{~d}-1$ (1982).

${ }^{6}$ Why stop there? One might with equal justification object that repeal of the income tax would violate the Fifth Amendment since that-like an exemption-would release to dis- 
thing for nothing in this context, Congress and the courts seem to agree that keeping "your own" money rather than paying it in taxes does not count as "something."

The Court has reached a similar result in Establishment Clause cases for similar reasons. As it said in Walz v. Tax Commissioner: "The grant of a tax exemption is not sponsorship since the government does not transfer part of its revenue to churches but simply abstains from demanding that the church support the state."67

\section{WHO IS A "RECIPIENT"?}

A persistent tactic of those who want to give aid to parochial schools has been to structure the transaction so that the aid is formally given to the child or to the parents. This approach has had some, but not uniform, success. It was an argument the Court rejected in Grand Rapids: ${ }^{68}$

Petitioners claim that the aid here, like the textbooks in Allen, flows primarily to the students, not to the religious schools. ... Where, as here, no meaningful distinction can be made between aid to the student and aid to the school, "the concept of a loan to individuals is a transparent fiction."

Identical questions have arisen under the antidiscrimination statutes, and the results have been parallel. In both areas the difficulty has been making a "meaningful distinction . . . between aid to the student and aid to the school."

1. General purpose assistance for individuals. That there is a difference is not open to doubt. One who receives welfare ${ }^{69}$ or Social Security ${ }^{70}$ payments may spend them at a sexist institution without subjecting himself or the institution to the requirements of Title IX. And the same money can be given to a church or a parochial school without creating any Establishment Clause questions. ${ }^{71}$ The

criminating institutions money that belongs to the government. The argument would be vulnerable to the objection that the government had no discriminatory intent, though that claim might not be successful if the plaintiff chose his defendant carefully. See note 20 supra.

67397 U.S. 664,675 (1970).

${ }^{68} 105$ S.Ct. at 3229.

${ }^{69}$ See Grove City, 104 S.Ct. at 1218 n.13.

${ }^{70}$ See Soberal-Perez v. Heckler, 717 F.2d 36 (2d Cir. 1983) (Title VI). See also 45 C.F.R. Pt. 84, App. A, p. 302 (1984) (HHS $\$ 504$ regulation) (Medicare); 110 Cong. Rec. 10076 (1964) (letter of Atty. Gen. Kennedy regarding agricultural support payments) (Title VI).

${ }^{11}$ See Choper, The Establishment Clause and Aid to Parochial Schools, 56 Calif. L. Rev. 260, 316-17 (1968). 
government is not seen as the cause of forbidden effects in such cases. The reason is that the law here, as elsewhere, is unwilling to follow a chain of causation back beyond a voluntary and unforeseen human act in order to explain or attribute responsibility. ${ }^{72}$ In making such grants the government has no way of knowing how they will be spent and no practical means of controlling expenditures. The individual beneficiary chooses what to do with the money, uninfluenced by anything the government has done. The case is otherwise when the government gives aid directly to an institution that propagates religion (or promotes discrimination). Then the government should foresee, and can control, the effects of its action. In fact, to take an intermediate case, the result is also different when the government gives aid to individuals in a form that can only be used at such an institution. ${ }^{73}$

2. Tax benefits for individuals. Let me first mention a problem one step short of the intermediate case-tax breaks for individuals who contribute money to religious or discriminating institutions. The Court has never suggested that the charitable deduction for contributions to churches is suspect under the First Amendment. ${ }^{74}$ And in Mueller $v$. Allen it held that a deduction for tuition paid to parochial (or other) schools was not forbidden aid to the schools. ${ }^{75}$ The outcome seems to be the same when deductions are taken for contributions to institutions that discriminate. ${ }^{76}$

One approach to justifying the practice has been to emphasize

72 "If a guest sits down with a table laid with knife and fork and plunges the knife into his hostess's breast, her death is not in any context thought of as caused by, or the effect or result of the waiter's action in laying the table[.]" Hart \& Honoré, Causation in the Law 66 (1959). This is the paradigm adopted by the Court in Witters, note 32 supra, which approved the expenditure of state vocational rehabilitation assistance money at a Bible college. 54 USLW at 4136 .

73 "If the murder occurred in a prison dining hall, ... where knives are never set on tables and diners may be expected to get violent, then the laying of the table would be the abnormal everit of great explanatory power, and the provision of opportunity 'the cause.' The pertinent principle here is that the more expectable buman bebavior is, wbetber voluntary or not, the les likely it is to "negative catsal comnection[.]" Feinberg, Doing and Deserving 166 (1970) (emphasis in original).

${ }^{74}$ See Nyquist, 413 U.S. at 790 n.49.

${ }^{75} 463$ U.S. 388 (1983).

${ }^{76}$ McGlotten v. Connally, note 64 supra, which held that exemptions for fraternal organizations counted as "financial assistance," also held that deductions for contributors subjected such organizations to Title VI. $338 \mathrm{~F}$. Supp. at 462. This conclusion, like the first, has never been followed. The question can no longer arise under Title VI after Bob Jones University v. United States, 461 U.S. 574 (1983), though it may under Title IX, \$ 504, and the ADA. 
that (as with Social Security) the benefit to an institution is "ultimately controlled by the private choices of individual parents."77 That will not work. The government knows exactly what parents will take the deduction for (tuition); the only question is whether they will take it. The real explanation for these cases is not that the school is not a "recipient" but that tax deductions for contributors-like tax exemptions for the schools-do not count as "financial assistance."

3. Tuition. That explanation of the tax benefits rule is confirmed by the intermediate case: tuition grants. Grove City held that a college whose students paid for their education with Pell grants "receive[d] Federal financial assistance" within the meaning of Title IX. ${ }^{78}$ And Committee for Public Education $v$. Nyquist held that a New York tuition reimbursement program for students at private grade and high schools was really "assistance to private schools."79 Such grants are different from Social Security because the government foresees, indeed intends, that they will be spent at educational (parochial) institutions. ${ }^{80}$ On the other hand, such grants differ from tax deductions because their effects are, as the Court put it in Grand Rapids, "unmediated by the tax code."

${ }^{77}$ Mueller v. Allen, 463 U.S. at 400 . Hence the emphasis, in all these "child benefit" cases, on whether the aid is available to public as well as to private school children. Id. at 398; Nyquist, 413 U.S. at $782-83$ n.38. If it is, one can argue that the state doesn't really know what use a parent will make of the aid (whether he will use it in public school, in a private secular school, or in a parochial school), just as it does not know how Social Security benefits will be spent. And so, the argument concludes, the state can't be considered the cause of any unforeseen religious effects. See Witters, note 32 supra, at 4136-37.

78104 S.Ct. at 1216-20.

79413 U.S. at 783. The Court's summary affirmances in Americans United for Separation of Church and State v. Blanton and in Smith v. University of North Carolina, note 32 supra, might suggest that the Establishment Clause treats college scholarships differently. Both cases at least hold that scholarships that college students may use at any public or private school do not necessarily have an unconstitutional effect of promoting religion when they are used at religious colleges. That, however, is entirely consistent with my point, which is simply that a school is a "recipient" of aid when students spend scholarships there. As I shall suggest later, to prove an Establishment Clause violation one must also show that the aid goes to a "program or activity," within the "recipient" institution, where religious practices occur.

80 "[G]eneral assistance programs, unlike student aid programs, [are] not designed to assist colleges and universities. . . [I]ndividuals' eligibility for general assistance is not tied to attendance at an educational institution." Grove City, 104 S.Ct. at 1218 n.13. "[I]t is precisely the function of New York's law to proxide assistance to private schools, the great majority of which are sectarian." Nyquist, 413 U.S. at 783.

${ }^{81} 105$ S.Ct. at $3229 \mathrm{n} .13$. I should here say something about the tax credit to parents that was condemned in Nyquist. 413 U.S. at 789-794. Nueller v. Allen admitted that "the economic consequences of [that] program [were] difficult to distinguish" from the deduction that the Court upheld. 463 U.S. at 397 n.6. I agree. What made it impossible to sustain the 
4. Materials and services for individuals. These crucial features of tuition grants are shared by books, bus rides, and other materials and services (diagnosis, therapy, counseling, remedial help). All those kinds of aid can be structured as assistance to child or parent, but such an arrangement should not in itself exonerate the government from responsibility for religious indoctrination. As may be seen from column A and column B in table 1, however, the Court has approved some such arrangements and not others. The reason is that, under the Establishment Clause and under Title IX, there is still a further question: whether the aid goes to any "program or activity" where forbidden conduct is occurring.

\section{WHAT "PROGRAM OR ACTIVITY" IS ASSISTED?}

Like the "financial assistance" and "recipient" rules, the "program or activity" rule is concerned with the effects of government aid. The "financial assistance" rule eliminates certain government actions (procurement, tax exemptions) as not causally relevant. The "recipient" rule deals with aid delivered to institutions through intermediaries, who may sometimes sever the causal nexus. The "program or activity" rule assumes that there are discontinuities within institutions-that aid to one aspect of a school's affairs does not necessarily produce effects everywhere else in the school. Seven theories have been used to explain what intrainstitutional effects are forbidden.

1. Purpose. The most obvious reason for holding government responsible for private discrimination, or private religious activity, is that it has intended its assistance to cause such effects. One would expect the law to be rather unforgiving in blaming government for effects when it has such a purpose, much as it is in blaming a defendant for remote damages caused by intentional torts or in finding complicity in someone else's criminal conduct. ${ }^{82}$ The

credit in Nyquist was that it was integrated with the system of tuition grants to produce a carefully graduated benefit scale. 413 U.S. at 764-67. To have held only the grants invalid would have eliminated benefits for the poor (those with incomes of less than $\$ 5,000$ ) while approving them for the rich. That was something the Court just couldn't bring itself to do.

${ }^{82}$ See, e.g., A.L.I. Restatement (Second) of Torts $\$ 435 \mathrm{~B}$, comment a (1965) ("responsibility for harmful consequences should be carried further in the case of one who does an intentionally wrongful act than in the case of one who is merely negligent or is not at fault"); A.L.I. Model Penal Code and Commentaries (Official Draft and Revised Comments) § 2.06, comment 6(b) (1985) ("One who solicits an end, or aids or agrees to aid in its achievement, is an accomplice in whatever means may be employed, insofar as they constitute or commit an offense fairly envisaged in the purpose of the association."). 
issue is pretty much hypothetical, though. The courts rarely find evil intentions in government assistance programs. ${ }^{83}$

2. Opportunity. As a practical matter, when we say that the government has caused improper "effects" we do not mean that its conscious objective is to achieve such results. We do not even mean that the government has unwittingly made something happen. There are voluntary actions by people in the institution that intervene between the government's act and its "effects," 84 and it would be strange to say that the government "made" those people engage in religious or discriminatory activity. What we really mean, most often, is that the government has provided an opportunity for the institution to misbehave. It is as though the government has left the keys in a parked car, which a thief drives away. Or better, it is like the opportunity for harm that a Dram Shop Act seeks to prevent. ${ }^{85}$

Suppose that a bartender gives his customer a free drink (to make the dram shop case look like "financial assistance" rather than procurement). The most obvious cause-and-effect relation envisioned by a Dram Shop Act is that the customer will get drunk and injure himself or someone else. If he does, the bartender is held responsible. Other consequences are possible too. The customer may linger over his drink, when he should be at work, and get fired. Or he may spend the money he saves on his free drink with a bookmaker. But we would not say that the bartender was the cause of the customer's unemployment or gambling. Those harms do not exploit the dangerous aspects of the opportunity that he provided.

The Opportunity Theory envisions something like the first type of harm in this example. Title IX worries in large part that customers (recipients) will put the sustenance they are given (federal dol-

${ }^{83}$ The purpose prong of the Lemon test has been invoked only in cases where the government itself has engaged in religious activity. See, e.g., Wallace v. Jaffree, 105 S.Ct. 2479 (1985); Stone v. Graham, 449 U.S. 39 (1980). At the time Title VI was passed there were several federal aid programs that authorized recipients to spend assistance under a "separate but equal" formula, 7 U.S.C. $\$ 323$ (1958) (Second Morrill Act); 20 U.S.C. \$636(b)(1)(1F) (1958) (impact aid); 42 U.S.C. $\$ 291$ e(f) (1958) (Hill-Burton Act), and much was made of these in the debates. 110 Cong. Rec. 1527-1528 (Rep. Celler), 6544 (Sen. Humphrey), 7054, 7057, 7062 (Sen. Pastore) (1964). We have problems nowadays, but not of this kind.

${ }^{84}$ In the "recipient" problems discussed above there are actually two intervening voluntary actions: one by the individual who first gets the assistance and one by the institution to which it is remitted.

${ }^{85}$ But with this difference: in the parochial school case we take away the bartender's license (declare the aid statute unconstitutional); in the discrimination case we only take away the customer's drink (revoke the aid). 
lars) to harmful use (discrimination). ${ }^{86}$ To avoid that harm it suffices to trace the federal dollars and insist that they be spent for proper purposes.

If this were the only harm Title IX was concerned with, the term "program or activity" would refer to the federal grant program (e.g., Pell grants) rather than to some program conducted by the recipient (a college financial aid program) that includes both federal and school money. It would not matter if the recipient caused harm with its own time or money; what would count is what it did with the drink. Many of the early Title VI cases emphasized this point, ${ }^{87}$ though the Supreme Court took a broader view in Grove City.

The Court has also flirted with the Opportunity Theory for aid to religious colleges. Roemer v. Maryland Public Works Board held that a state could give noncategorical grants to private (including religious) colleges, provided the schools segregated the funds in separate accounts, agreed not to spend the money for sectarian purposes, and accounted for the funds at the end of the year. ${ }^{88}$ The important thing was the assurance that the government's money would not itself be misused: "if secular activities can be separated out, they . . . may be funded." 89

86 "That principle is [that] taxpayers' money, which is collected without discrimination, shall be spent without discrimination." 110 Cong. Rec. 7064 (1964) (Sen. Ribicoff) (Title V1). "Here we have this scholarship money-much of it federal-going to students. Which students receive this scholarship money is decided upon by the individual colleges and universities-where there are often quota restrictions on women recipients." Discrimination Against Women: Hearings on Section 805 of H.R. 16098 Before the Special Subcomm. on Education of the House Comm. on Education and Labor, 91st Cong., 2d Sess., Pt. 1, at 235 (1970) (Rep. May) (Tizle IX).

${ }^{\mathrm{s} 7}$ See, e.g., Board of Public Instruction of Taylor County, Fla. v. Finch, 414 F.2d 1068, 1077 (5th Cir. 1969) ("the school lunch program, *** the agricultural extension program for home economics teaehers, $* * *$ the farm-to-market road program"). This is also the most natural reading of some of the statutory language. Title IX speaks, for example, of "termination of . . . assistance under such program or activity to any recipient" and says that termination reports have to be filed "with the committees on the House and Senate having legislative jurisdiction over the program or activity involved[.]" 20 U.S.C. $\$ 1682$ (1982) (emphasis added).

${ }^{88} 426$ U.S. 736 (1976). Regan upheld cash payments to lower schools on the same theory. The payments there were reimbursement for the costs of recordkeeping and of administering and grading state-prepared tests. 4.S. at 657-59.

${ }^{80}$ Id. at 755 (opinion of Blackmun, J.) (emphasis omitted). Roemer was a challenge to Maryland's statute on its face, so the Court had no occasion to say how much space had to be left around secular activities when they were "separated out"-e.g., whether the entire French department (the recipient's "program") had to be free of religious taint before money could be spent there. If it did, the relevant effects would include not just opportunities but also symbolism. See pages $83-85$ infra. 
The government can often avoid the consequences of this theory by providing assistance in kind rather than in cash. That technique has succeeded for books, tests, and diagnostic services delivered to parochial schools on their premises (see col. A, table 1). Such aid is thought to be self-policing: it does not create any opportunity for abuse and so cannot be said to cause any forbidden effects. It is as though the bartender in the dram shop gave his customer a glass of water rather than something more potent. But Grand Rapids, like Grove City, takes a view of forbidden effects that is broader than the Opportunity Theory allows for. The Court does not look only at the government grant program.

3. Infection. One justification for reaching out beyond the grant program to other parts of the institution might be called the Infection Theory. The idea is that misbehavior elsewhere in the school (upstream, as it were, from the grant program) can infect the use of government funds and should therefore be covered as well. The Infection Theory thus adds one link to the chain described in the previous section.

An example under Title IX is admissions. In Cannon v. University of Cbicago the Court allowed a female applicant to challenge a medical school's admissions practices without any showing that federal money was spent on admissions. ${ }^{90}$ The reason may have been that federal aid was extended to other parts of the medical school, and the school would give it all to men if women could not get in the front door. ${ }^{91}$ A more difficult infection question would be presented if the medical school got federal money to teach anatomy and discriminated against women by barring them from a school honor society. ${ }^{92}$

In deciding whether Title IX covers such outside activities, these cases have not insisted on a showing that federal money was misspent. They have instead relied on regulations-delineating the

\footnotetext{
90441 U.S. 677, 680-81 (1979).

${ }^{91}$ Rice v. President and Fellows of Harvard College, 663 F.2d 336, 339 n.2 (1st Cir. 1981), cert. denied, 456 U.S. 928 (1982); Othen v. Ann Arbor School Board, 507 F. Supp. 1376, 1388 (E.D. Mich. 1981), aff'd, 699 F.2d 309 (6th Cir. 1983). Norwood v. Harrison, 413 U.S. 455,469 (1973), applied this same theory as a matter of constitutional (rather than statutory) law to racially segregated schools.

${ }^{92}$ See Iron Arrow Honor Soc. v. Heckler, 702 F.2d 549 (5th Cir. Unit B), vacated and remanded, 104 S.Ct. 373 (1983).
} 
path that infection can be expected to follow ${ }^{93}$ - that permit them to assume that the ultimate forbidden effect (abuse of the federal grant funds) occurs once discrimination is shown outside the grant program.

Grand Rapids relied on the Infection Theory for its first effects argument. The Court found that "the presence of the [parochial school] environment" might cause even public school teachers to "conform their instruction to the environment." 94 There is a kind of fox-guarding-the-chickens plausibility to this with regard to the Community Education program, which was taught in large part by parochial school teachers hired pro bac vice by the school district. It is downright implausible as to the Shared Time program, which was taught almost entirely by full-time public employees who had no connection whatever with the schools to which they were assigned. ${ }^{95}$

The presumption that infection would occur is not just implausible; it is contradicted by the evidence of nineteen years' experience with the Title I program in Aguilar. ${ }^{96}$ And there are no agency regulations on which the Court can rely, as it does in discrimination cases, for support of its unproved empirical assumptions. One may ask why, in that event, the Court adhered to this dubious causal inference. The answer is the entanglement theory, which, as I will show, disqualified the Court from looking at the evidence. The situation is a bit like the flat-earth problem in the thirteenth century. The Court has adopted a view of the world that is immune from refutation because the very nature of the Court's view makes it unwilling to gather evidence.

4. Benefits. This theory is something like the Infection Theory run in reverse. The Infection Theory holds that discrimination (or religion) upstream from the grant program can flow into and corrupt it. The Benefits Theory holds that an innocent grant program

\footnotetext{
${ }^{33}$ See Iron Arrow, 702 F.2d at 554; 34 C.F.R. § 106.31(b)(7) (1984) (school support of student social organizations); 34 C.F.R. $\$ 106.15$ (c) (1984) (ED Title IX admissions regulation); 45 C.F.R. $\$ 84.42$ (a) (1984) (HHS $\$ 504$ admissions regulation).

of 105 S.Ct. at 3225 , quoting Wolman, 433 U.S. at 247 . The Court reached the same conclusion in Meek, 421 U.S. at 370-72, and Lemon, 403 U.S. at 617.

${ }^{95}$ See 105 S.Ct. at 3231 (O'Connor, J., concurring in part and dissenting in part).

${ }^{96} 105$ S.Ct. at 3245 (O'Connor, J., dissenting).
} 
can sometimes provide a benefit to discrimination (or religion) that occurs downstream. This theory has had mixed success in discrimination law, but more in religion cases.

One example of the Benefits Theory is tuition grants, which can be passed on from one program to another. Grove City rejected the argument that Title IX should cover every classroom and activity at the college because Pell grants went from the financial aid office into the general operating budget and out again in every direction. ${ }^{97}$ Committee for Public Education v. Nyquist reached the opposite conclusion about tuition grants to parochial school students. ${ }^{98}$

A different kind of example concerns government aid that is used up in program $x$ with side effects on program $y$. Suppose that the government gives money for teaching math classes and that students who take the classes do better in physics as a result. The Title IX regulations suggest that both physics and math are covered. ${ }^{99}$ It is not clear whether they survive Grove City. Grand Rapids may also have had something like this in mind when it said that "state programs providing [instructional materials and services] advance[] the 'primary, religion-oriented educational function of the sectarian school." "100 The Court may have meant that remedial reading classes make the school's own reading classes a more effective way of putting religion across.

The Benefits Theory of causation depends (as the Infection Theory does) on the more basic idea of providing an opportunity that the institution can exploit for purposes of discrimination or religion. The fear about tuition grants is that the school will misspend the government's money after moving it from one pocket to another. Insofar as it lends itself to that abuse, tuition looks like noncategorical aid that can benefit almost any part of the institu-

97 "[We] have found no persuasive evidence suggesting that Congress intended that the Department's regulatory authority follow federally aided students from classroom to classroom, building to building, or activity to activity." $104 \mathrm{~S}$.Ct. at 1222.

98 "The tuition grants here are subject to no . . . restrictions. There has been no endeavor 'to guarantee the separation between secular and religious educational functions and to ensure that State financial aid supports only the former." " 413 U.S. at 783.

9934 C.F.R. \$ 106.11 (1984): "This Part . . . applies to every recipient and to each education program or activity operated by such recipient which receives or benefits from Federal financial assistance."

${ }^{100} 105$ S.Ct. at 3229, quoting Meek, 421 U.S. at 364. 
tion, and there is some sense in following it into every classroom as Nyquist does. ${ }^{101}$

The problem of side effects is more difficult. Suppose that the physics building at Grove City College is inaccessible to the handicapped. We might hold the government responsible for that if it paid for the physics building. But if it has only given money for teaching math, the opportunity that the school abuses is not the government assistance itself. It is a side effect (benefit) of that assistance that the school prevents the handicapped from utilizing. So too with remedial reading and religion: the parochial school does not touch the remedial reading classes but puts one of their benefits (increased literacy) to use in other classes where it teaches religion. ${ }^{102}$

These arguments stretch the idea of causation quite far. There is a sense in which Grand Rapids has contributed to the propagation of religious faith. But it has in the same sense contributed to the spread of pornography, the belief in creationism, and the growth of the Republican party since those are all things that increased literacy will lead one to read about.

5. Freed-up funds. In holding that the Grand Rapids programs were an "indirect subsidy" to parochial schools ${ }^{103}$ the Court may have had in mind not the Benefits Theory but a different kind of

to1 The contrary outcome in Grove City was based on indications of congressional intent (104 S.Ct. at 1221-22) that do not apply to Establishment Clause questions. The result is also different under the Establishment Clause where tuition assistance is given to students at religious colleges. See col. A. Since the cases approving such aid were only summary affirmances, see note 32 supra, one can only speculate about the reasons. One possible explanation is that in such cases, unlike primary and secondary school cases, the schools are not "pervasively sectarian." See Aguilar, 105 S.Ct. at 3237. It is thus far less certain that tuition funds, even after having been moved around from one program to another, will end up benefiting religious activity. This matters because we are less willing to attribute responsibility to the government for effects it cannot foresee when it acts-particularly if they are produced by another institution's intervening voluntary choice. See text at notes 107-10 infra. The district court in Smitb emphasized that the tuition aid there could not be spent at a seminary or bible college-institutions that, like lower parochial schools, would be pervasively sectarian. $429 \mathrm{~F}$. Supp. at 872 . But $f f$. Witters v. Washington Department of Services for the Blind, note 32 supra.

${ }^{102}$ Another possible side effect in the religion cases, more remote still, is that the remedial reading program paid for by the government will make it more likely that children will attend parochial school and receive the religious instruction offered in other classes there. That is a consequence the Court has not found sufficient in other cases. Nyquist, 413 U.S. at 775; Allen, 392 U.S. at 244; Everson, 330 U.S. at 17.

${ }^{103} 105$ S.Ct. at 3229 n. 12. 
ripple effect. The Freed-up Funds Theory says that, even if the government aid is not itself abused, and even if it has no benefits that spill over into other programs, the institution may work new harm with the money that government aid displaces in its budget. If the federal government gives a college $\$ 500,000$ to spend on teaching physics, the college may then take $\$ 500,000$ of its own money out of the physics budget to spend on men's athletics. The Freed-up Funds Theory is one that several courts found persuasive in antidiscrimination cases ${ }^{104}$ before the Supreme Court rejected it in Grove City. The movement in religion cases has been in the opposite direction: the Court consistently rejected the theory before Grand Rapids, ${ }^{105}$ which might be understood to have resurrected it.

Like the Benefits Theory, this theory holds that the government causes all the ripple effects that flow from its assistance. Grove City picks out two obvious weaknesses with this idea. First, the government aid may not really cause any diversion of funds. ${ }^{106}$ If someone gives me an automatic garage door opener, I won't have more money to spend on other things, if I should never have purchased a garage door opener for myself. Second, if money is freed up, it may be very hard to tell where it goes, and it may not go toward forbidden acts. ${ }^{107}$ This matters because we are less willing to attribute responsibility for effects one cannot foresee when he actsparticularly if they are produced by another person's intervening voluntary choice. (Remember the problem of Social Security.) We would not say that the bartender was the cause of the customer's gambling, even though the customer may have had no funds to gamble with had the bartender not given him a free drink.

If we assume that parochial schools are "pervasively sectar-

${ }^{104}$ See, e.g., Grove City College v. Bell, 687 F.2d 684, 696 (3d Circ. 1982), rev'd, 104 S.Ct. 1211 (1984) (Title IX); Haffer v. Temple University, 688 F.2d 14 (3d Cir. 1982) (Title IX); Wright v. Columbia University, 520 F. Supp. 789, 792 (E.D. Pa. 1981) (\$ 504); Poole v. South Plainfield Bd. of Ed., 490 F. Supp. 948, 951 (D.N.J. 1980) ( $\$ 504$ ); Bob Jones University v. Johnson, 396 F. Supp. 597, 602 (D.S.C. 1974), aff'd, 529 F.2d 514 (4th Cir. 1975) (Title VI).

${ }^{105}$ See, e.g., Regan, 444 U.S. at 658 ; Roemer, 426 U.S. at 747 (plurality opinion); Hutt, 413 U.S. at $743 ;$ Nyquist, 413 U.S. at 775; Tilton, 403 U.S. at 679 (plurality opinion); Lemon, 403 U.S. at 664 (opinion of White, J.). Cf. Catbedral Academy, 434 U.S. at 134.

${ }^{106} 104$ S.Ct. at 1221.

${ }^{107}$ Ibid. 
ian," 108 this second point loses force. In that case the government might foresee that almost anything for which the freed-up funds will be spent will be religious. But there are still several problems with saying that the government has caused religious effects. In other religion cases, ${ }^{109}$ as in Grove City, the Court has not been willing to assume that government aid for nonessentials actually frees up funds. And the evidence in Grand Rapids showed that the parochial schools had not previously offered the challenged courses. The Court's response was that there was no way of knowing that they would not have done so in the future ${ }^{110}$ - a kind of counterfactual conditional not subject to rebuttal.

A third kind of problem with the Freed-up Funds Theory is that it applies to a surprising variety of causes. One may say that remedial reading services free up money for teaching religion, but one could with equal justice point to city sewer services as a cause of the same effect. If the city did not provide sewer service, the parochial schools would have to install septic tanks, and you can buy a lot of catechisms for what you'd spend on a septic tank. ${ }^{111}$

It is true that reading is part of the curriculum (a point emphasized in Grand Rapids) and sewers are not. ${ }^{112}$ But that actually counts against this theory. When school money earmarked for septic tanks is freed up and spent on religion, there is a net gain in funded religious activity. School money budgeted for the curriculum, however, is already going for religious activity, ${ }^{113}$ so moving it somewhere else may cause no new harm. If the Shared Time program has actually erased religion from " 10 percent of the school day," 114 it is queer to say that the program has caused religious effects simply because the school looks for a way to make up the time.

\footnotetext{
${ }^{108}$ Grand Rapids, 105 S.Ct. at 3223.

${ }^{109}$ See, e.g., Allen, 392 U.S. at 244 n.6.

110105 S.Ct. at 3230.

111 This argument impressed the Court in Regan, 444 U.S. at 658 \& n.6, and Roemer, 426 U.S. at 747 (opinion of Blackmun, J.).

112105 S.Ct. at 3230.

113 That is the basic assumption behind saying that the government cannot aid the school's "educational function" (105 S.Ct. at 3229)-the curriculum is "pervasively sectarian" (id. at
} 3223).

${ }^{114} 105$ S.Ct. at 3230. 
6. Proof problems. The paradigm cause-and-effect relation in all the theories I have discussed so far is one where the government provides an opportunity for harm that the institution exploits. For all of these theories the relevant "program or activity" is the government grant program, though activities elsewhere in the institution may also be covered if they infect, or benefit from, or are funded by money freed up by, the government's program. But suppose that the government contributes half the cost of building a school library and that the school contributes the other half. It would be arbitrary, given the way libraries are built and paid for, to say that the government's money built one part of the library and the school's another or that the government's money paid for the first twenty years of its useful life and the school's for the remainder. Even if the effect we worry about is misuse of the government's money, the impossibility of tracing it requires us to say that the "program or activity" here is the recipient's program, not the grant program. This is what the antidiscrimination regulations and the Establishment Clause cases say about construction grants. ${ }^{15}$

Grand Rapids and Aguilar may accept a variation on this theory. One way of expressing their conclusion is to say that the relevant "program or activity" is the school's entire educational program, ${ }^{16}$ not the government assistance program. But one cannot rely on the Proof Problems Theory for that conclusion. There was no ambiguity in either case, as there is with construction grants, about where the government's money went. Nor was there any ambiguity in the other cases (see col. B, table 1) where states supplied materials or services, rather than cash, for use on the parochial school premises. The question in all these cases was not where the assistance went but whether harm occurred (whether religion was sponsored by the government's contribution).

The Court said in Grand Rapids that it can be hard to prove the fact of harm, just as it is hard to trace government funds. We cannot require taxpayer plaintiffs to show harm in schools they do not attend, the argument went, when no one at the school has an

${ }^{115}$ As to paying for part of a building, compare Nyquist, 413 U.S. at 774-79, with 45 C.F.R. $\$ 80.5(\mathrm{e})$ (HHS Title VI regulation). As to paying for part of a building's useful life, compare Tilton, 403 U.S. at $674-75,681-84$, with 34 C.F.R. $\$ 106.4(b)(1)$ (ED Title IX regulation).

116105 S.Ct. at 3229 ("educational function"). 
incentive to report abuses. ${ }^{117}$ But the government itself can monitor for harm, as it did in Aguilar. ${ }^{118}$ The real reason the Court presumed harm was not proof problems but the discovery process. Aguilar makes this clear: ${ }^{19}$

When the state [monitors for harm] the freedom of religious belief of those who are not adherents of that denomination suffers, even when the governmental purpose underlying the involvement is largely secular. In addition, the freedom of even the adherents of the denomination is limited by the governmental intrusion into sacred matters.

The solution to the discovery problem is the same as the solution to the proof problem: define "program or activity" more broadly than the government assistance program. The outer limits are fixed by the area in which discovery is likely to cause problems. In lower school cases the program is the education program on the school premises. In the case of colleges, which are not "pervasively sectarian," discovery presents no problem and this theory does not apply.

Whether this variation on the Proof Problems Theory is a convincing reason for expanding the notion of "program or activity" depends on the assumption that discovery really does cause problems. I will argue later that it does not.

7. Symbolism. The other effect on which Grand Rapids relied, unlike all of those up to this point, has nothing to do with the recipient abusing opportunities. The Court said that the government would also improperly aid religion if it "convey[ed] a message of . . . endorsement or disapproval of religion." In Grand Rapids the message was sent via symbols: "the symbolic union of church and state" in one joint enterprise. ${ }^{120}$ It's as though the school paid for religious activity with its own money, but its partner the government said, "We are in this together."

In this instance, as in the last (Proof Problems), the relevant "program or activity" is not the government grant program but something broader-the joint venture in which government and school

${ }^{117} 105$ S.Ct. at 3225-26.

118 "[T]he supervision in this case would assist in preventing the Title I program from being used, intentionally or unwittingly, to inculcate the religious beliefs of the surrounding parochial school." 105 S.Ct. at 3236-37.

${ }^{119}$ Id. at 3237 .

${ }^{120} 105$ S.Ct. at 3226. 
are engaged. This might explain why Grove City held the college's financial aid program, not just the Pell grant program, subject to Title IX. ${ }^{121}$ To hold otherwise could suggest that the government approved of sex discrimination carried on by the school with its own scholarship funds.

The obvious problem with the implementation of this theory is defining the scope of the joint venture. In Grove City it did not encompass any classes the school gave, even though the government was paying tuition for all of them. In Grand Rapids it seemed to include all classes, even though the government was only offering a few. The Court said that the scope of the joint venture there was determined by the public's (and especially the parochial school student's) perception: ${ }^{122}$

[The question] is whether the symbolic union . . . is sufficiently likely to be perceived by adherents of the controlling denominations as an endorsement, and by the nonadherents as a disapproval, of their individual religious choices. ... The symbolism ... is most likely to influence children of tender years.

I am not sure that a Gallup poll would measure this effect any better than the Court's intuitive method does, but my own intuition is different. The private religious activities of the government's joint venturers are, unlike discrimination, something the Constitution protects and deems valuable. That is why Norwood v. Harrison said that government can give free books to religious schools but not to segregated schools. ${ }^{123}$ So, if English classes are not covered in Grove City, a fortiori they should not be covered in Grand Rapids. It is harder to see endorsement when the government's partner does things the government has no control over than when it does things the government could forbid but does not.

There is another difficulty with the Court's conclusion about symbolic effects. Remember that we are speculating about people's impressions of how the government views its joint venturer's reli-

${ }^{121}$ The Court did not say why it chose the recipient's program, rather than the grant program, as the relevant unit for purposes of coverage. It simply said that "students who participate in the College's federally assisted financial aid program but who do not themselves receive federal funds [arel protected against discrimination on the basis of sex." 104 $\mathrm{S} . \mathrm{Ct}$. at $1221 \mathrm{n} .21$. Some of the statutory language supports this conclusion. Section 901(a) speaks, for example, of an "education program or activity receiving Federal financial assistance." 20 U.S.C. \$ 1681 (a) (1982). But see note 87 supra.

122105 S.Ct. at 3226.

123 Note 91 supra. 
gious activity. It seems as though the government could neutralize any symbolic effects by making perfectly clear that it did not approve of what its partner was doing. New York succeeded fairly well at that in Aguilar: "[T]he religious school . . . must endure the ongoing presence of state personnel whose primary purpose is to monitor teachers and students in an attempt to guard against the infiltration of religious thought." 224 No one would suppose that the government in that case applauded the schools' religious activities. But this most obvious means of neutralizing symbolic effects is forbidden by the entanglement rules.

\section{E. REPRISE}

The antiestablishment and antidiscrimination principles are sufficiently similar that one could restate the Lemon test in the terms used by Title IX without causing any real change in the results of the cases. ${ }^{125}$ The rephrased test would read:

No person in the United States shall . . . be [given religious instruction] in .... any education program or activity receiving Federal [or State] financial assistance.

With but one exception the terms "financial assistance," "receiving," and "program or activity" have the same meaning and scope as they do under Title IX. The exception is that, in cases involving aid to parochial grade and high schools, the term "education program or activity" means the entire on-premises educational function of the school. ${ }^{126}$ Any government contribution to on-premises education must be cut off because students are receiving religious instruction in that program.

This reading of "program or activity" is broader than what Grove City says Title IX would require. Under the antidiscrimination

\footnotetext{
124105 S.Ct. at 3239.

125 This is slightly overstated. See note 126 infra.

126 Education assistance (therapeutic, counseling, remedial, accelerated, and supplemental services) can be given to parochial school students off campus. See col. A. Bus rides for field trips do not fall within this category, perhaps because the tcacher goes along. See col. B and Wolman, 433 U.S. at 253. Aid that does not contribute to the educational process (lunch, diagnostic services) can be provided on campus. See col. A. Given this expansive definition of "education program or activity," I cannot account for allowing books or tests (nor reimbursement for tests). See col. A. But the Court has as much as said that it cannot either, Wolman, 433 U.S. at $252 \mathrm{n}$. 18, so I shall not apologize for this shortcoming. See also note 81 supra (on the problem of tax credits).
} 
principle it would be appropriate to distinguish between a high school's industrial arts program, or its athletics program, and its program for use of Title I funds. ${ }^{127}$ As the Court said in Grove City, "[W]e have found no persuasive evidence suggesting that Congress intended that the Department's regulatory authority follow federally aided students from classroom to classroom . . . or activity to activity." 128

This difference between parochial school and Title IX cases results from the Court's greater willingness to find intrainstitutional religious effects under nearly all of the "program or activity" theories I discussed. In Grand Rapids the Court assumed that the parochial school atmosphere would infect Shared Time, notwithstanding a lack of evidence on that point (Infection Theory). lt said that both Shared Time and Community Education would have ripple effects (Benefits or Freed-up Funds) that promoted religion. But there was no evidence that funds were actually freed up or that, if they were, their expenditure resulted in a net increase in religious activity. ${ }^{129}$ In fact the Court dispensed altogether with proof of harm because it believed that the process of discovering harm would itself be detrimental to religion (Proof Problems). Finally, the Court worried about symbolic effects in Grand Rapids (Symbolism), though neither evidence nor intuition supported its concerns. And it forbade in Aguilar the very means for countering any symbolic effects that might occur.

To put it more briefly, the chief difference between parochial school and Title IX cases is that the former make strained assumptions about cause and effect that the entanglement rule precludes people from disproving. The decision in parochial school aid cases must depend entirely, as it did in Grand Rapids, on "risks" rather than on "effects," on what "might" happen rather than on what did. ${ }^{130}$

${ }^{127}$ See, e.g., Dougherty County School System v. Bell, 69+ F.2d 78, 81 (5th Cir. 1982); Finch, note 87 supra, 414 F.2d at 1078; Otben, note 91 supra, 507 F. Supp. at 1380.

128104 S.Ct. at 1222.

${ }^{129}$ And the benefits - things like literacy-have such a variety of applications that it seems arbitrary to pick out religious belief as the effect they primarily advance.

${ }^{130}$ See, e.g., 105 S.Ct. at 3223-24 ("may impermissibly advance religion"; "teachers . . . may become involved"; "programs may provide a crucial symbolic link"; "programs may ... provid[e] a subsidy"). As to the problem of infection, see id. at 3224-26 ("an unacceptable risk"; "[t]he potential for impermissible fostering of religion"; "too great a risk"; "a substantial 


\section{ENTANGLEMENT}

Aguilar said that the entanglement rule rested on two concerns that prevented the collection of evidence about improper effects. Both rely on unsupported speculation that other kinds of forbidden effects will occur if the government tries to monitor the services it provides. One concern is that the government, in administering assistance, will show too much favor for the recipient and thereby threaten nonmembers of the sect. The other is that "the freedom of even the adherents of the [school's] denomination is limited by governmental intrusion into sacred matters."131

\section{A. CAPTURE}

The first entanglement problem mentioned in Aguilar concerned the effect that administration of the aid program might have on people outside the school: ${ }^{132}$

When the state becomes enmeshed with a given denomination in matters of religious significance, the freedom of religious belief of those who are not adherents of that denomination suffers, even when the governmental purpose underlying the involvement is largely secular.

The phrase "enmeshed . . . in matters of religious significance" here refers to the issues that may arise when program administrators monitor teachers and classrooms to make sure that religion does not creep in.

The Court did not explain how this harm would come about, though one proposal has been that it is like the "capture" of administrative agencies by those they are supposed to regulate. ${ }^{133}$ Or to put the same idea in the terms I have been using, it's the Infection

risk"; "the pressures of the environment might alter his behavior"; "[t]eachers . . . may well subtly . . . conform their instruction"; "the absence of proof of specific incidents is not dispositive.") As to the problem of symbolism, see id. at 3226-27 ("sufficiently likely"; "students would be unlikely to discern the . . . difference"). As to the problem of subsidy, see id. at 3230 ("there is to way of knowing whether the religious schools would have offered some or all of these courses"; the schools "could surcly discontinue existing courses"; approval here would "let the genie out of the bottle").

131105 S.Ct. at 3237.

132 Ibid.

${ }^{133}$ Nowak, The Supreme Court, the Religion Clauses and the Nationalization of Education, 70 Nw. L. Rev. 883, 904 (1976). 
Theory at one remove. The Infection Theory says that public school teachers working in the Title I program in parochial schools may be swept up in the sectarian spirit of the enterprise and modify their instruction along religious lines. This variation says that administrators who go into the parochial schools to make sure that does not happen will catch the same bug and ignore or approve abuses they see in the program.

We have heard this kind of thing in school aid cases for so long now that I think we are inured to how really extraordinary it is. Suppose, just to make it sound fresh, that we transpose the same idea to Title IX. The modified Infection Theory in that context would say that a school subject to Title IX could for that very reason not receive federal aid because, in the process of looking for sex discrimination, Department of Education officials might be captured by chauvinists. I do not mean to deny that the problem of "capture" is sometimes a real one. But the mere possibility that it will occur cannot be a sufficient reason for refusing to give government aid because any program for giving assistance to institutions will require government supervision to assure that the aid is not abused. The only sensible solution ${ }^{134}$ is to deal with the problem if and when it happens by cutting off aid to the captors.

There is one possible difference between the two cases. Aguilar stressed that parochial schools are "pervasively sectarian," "135 and Title IX recipients are by and large not pervasively discriminatory. Perhaps capture is so much more likely in the former kind of case that it is not worth running the risk. The Court's treatment of religious colleges is consistent with this idea. They, unlike lower schools, are not "pervasively sectarian," and so the Court does not worry much about entanglement. ${ }^{136}$

The problem with this hypothesis is that it does nothing to explain why capture is more likely in a case like Aguilar. The people at risk there-Title I administrators-were supervising public school teachers, and it is hard to see a threat of entanglement in the government supervising its own employees. It does that in the public schools. The only contacts Title I administrators had with

\footnotetext{
134 "Deregulation" is not an option.

135105 S.Ct. at 3237.

136 See 105 S.Ct. at 3237-38. See also Roemer, 426 U.S. at 758-59; Tilton, 403 U.S. at 684-89; and Hunt, 413 U.S. at 745-49.
} 
parochial school personnel (the only time they risked capture or infection) concerned the time and place for classes, the choice of students, and reporting about performance. ${ }^{137}$ The latter two are things that would happen even if parochial school students went outside the building for Title I instruction. And none of those contacts can remotely be considered a "matter of religious significance."

The "capture" argument is so implausible that it is hard to believe that this first entanglement concern should make any difference. And in fairness to the Court, I must say that the opinion in Aguilar did not dwell on it. It was more interested in a second variety.

\section{B. INSTITUTIONAL AUTONOMY}

In addition to its statutory arguments against Title IX coverage, Grove City College claimed "that conditioning federal assistance on compliance with Title IX infringe[d] First Amendment rights of the College and its students[.]"138 The school did not contend that it had a right to discriminate against women. On the contrary, it said that "to engage in discrimination . . . would be repugnant to [its] moral principles[.]"139 Instead it argued that pervasive regulation by the Department of Education to enforce Title IX "would impermissibly interfere with the College's autonomy and the values which it seeks to promote among its students." $1+0$ Those values derived in large measure from religious principles (Grove City is affiliated with the United Presbyterian Church), ${ }^{1+1}$ but the First Amendment freedom the school feared for was academic and associational rather than religious. ${ }^{1+2}$

\footnotetext{
137105 S.Ct. at 3239.

138104 S.Ct. at 1223.

${ }^{139}$ Pet. Br. 48, Grove City College v. Bell, 10+ S.Ct. 1211 (1984). The case arose out of the college's refusal to execute an Assurance of Compliance with Title IX. The Department of Education then began administrative proceedings to terminate financial assistance (Pell grants) to the college and its students. Departmental regulations and the statute authorize termination for failure to execute an Assurance. 20 U.S.C. $\$ 1682$ (1982); 34 C.F.R. $\$ 106.4$ (1984); 104 S.Ct. at 1222-23. There was tbus no claim that the college had actually discriminated.
}

${ }^{1+0}$ Grove City College v. Bell, 687 F.2d at 701.

${ }^{1+1} I d$. at $688,701 \mathrm{n} .29$.

${ }^{1+2}$ Id. at 701 . 
The Court gave a short but sufficient answer to this claim: ${ }^{143}$

Congress is free to attach reasonable and unambiguous conditions to federal financial assistance that educational institutions are not obligated to accept. Grove City may terminate its participation in the [Pell grant] program and thus avoid the requirements of [Title IX]. Students affected by the Department's action may either take their [Pell grants] elsewhere or attend Grove City without federal financial assistance.

Since the college had no obligation to accept federal assistance in the first place, it could easily avoid the restrictions that it found so bothersome. In any event, Title IX's restrictions were quite "reasonable," given the Court's holding that the statute only covered Grove City's financial aid program. If the college accepted federal money, it could "segregate its activities according to the source of its funding"144 and would remain free to do as it wished outside the boundaries of the federally assisted program.

Grove City's argument has a familiar ring to it. It is the second entanglement argument the Court made in Aguilar: that "[a] comprehensive, discriminating, and continuing state surveillance"145 is "pregnant with dangers of excessive government direction of church schools." 146 The peculiar thing about the argument in religion cases is that it is never made by the schools, as it was in Grove City. It is instead made by plaintiffs challenging school aid, and accepted by the Court, in order to protect "the freedom of religious belief of ... the denomination[s]" running the schools. ${ }^{1+7}$ That peculiarity seems to make the argument even weaker. If the government can attach restrictions to aid over the recipient's objection without violating the First Amendment, it should certainly be able to do so with the recipient's consent.

There are several differences between the two cases that might make the analogy inapt. One is that the conditions on grants to parochial schools might not be as "reasonable" as they are in Title IX cases because the "program or activity" under surveillance is

\footnotetext{
${ }^{143} 104$ S.Ct. at 1223 (citation omitted).

${ }^{144}$ FCC v. League of Women Voters of California, 104 S.Ct. 3106, 3128 (1984). See Regan v. Taxation with Representation of Wash., 461 U.S. 540 (1983).

145105 S.Ct. at 3237, quoting Lemon, 403 U.S. at 619.

${ }^{1+6}$ Lemon, 403 U.S. at 620.

${ }^{147}$ Aguilar, 105 S.Ct. at 3237.
} 
broader. That is only true, however, because the Court is uniquely willing in religion cases to assume that improper effects will occur outside the boundaries of the grant program. A more realistic view of effects would resolve at one stroke the entanglement problem as well. ${ }^{1+8}$

A second difficulty with the analogy is that the First Amendment right relied on by Grove City College was academic freedom, while the threat to parochial schools concerns their "freedom of religious belief." I49 It is possible that the Court is more concerned about the latter right than about the former and is therefore willing to go to great lengths to protect schools (even against their own wishes) from "the bewitching power of governmental largesse." 150 The fear, I suppose, is that parochial schools will have to so change their practices in order to qualify for aid that they will lose much of their religious character-and will come to regret this in the end.

That the Court is more solicitous of religious freedom than of other First Amendment freedoms is a proposition that has some support. The odd thing is that the cases substantiating it show a greater willingness to give government money to free exercise

${ }^{1+8}$ That solution to the problem is strongly supported by League of Women Voters, note 145 supra. The Court there held invalid $\$ 399$ of the Public Broadcasting Act, 47 U.S.C. $\$ 399$ (1982), which forbids broadcasting stations that receive grants from the Corporation for Public Broadcasting to engage in editorializing. Congress enacted that section because it feared that recipients would "promulgate [their] own private views on the air at taxpayer expense" (104 S.Ct. at 3130 (Rehnquist, J., dissenting)), just as the Court has adopted institution-wide effects rules because it fcars that recipients will promote religion at taxpayer expense. League of Women Voten held, however, that an institution-wide prohibition violated First Amendment freedoms of speech and press:

[A] noncommercial educational station that receives only $1 \%$ of its overall income from CPB grants is barred absolutely from all editorializing. ... . [Such] a station is not able to segregate its activities according to the source of its funding. The station has no way of limiting the use of its Federal funds to all noneditorializing activities, and, more importantly, it is barred from using even wholly private funds to finance its editorial activity.

Of course, if Congress were to adopt a revised version of $\$ 399$ that permitted noncommercial educational broadcasting stations to [segregate their activities and] use the station's facilities to editorialize with non-federal funds, such a statutory mechanism would plainly be valid.

Id. at 3128 . In short, the Constitution actually requires a narrower ("program-specific") view of the effects of government grants where the recipient institution wants to exercise some kinds of First Amendment freedoms with its own money. Why that view should be limited to freedoms of speech and press, and not extend to religion, is not clear.

14? 105 S.Ct. at 3237.

${ }^{150}$ League of Women Voters, 104 S.Ct. at 3122. 
claimants (and to dispense with restrictions) than to those asserting other freedoms. ${ }^{151}$ Moreover, this difficulty, like the last one, varies with the scope of the restrictions that attend government grants. If the recipient school is required to do no more than refrain from putting the government's money to religious ends, it is hard to see how the government has worked any change in the extent of religious exercise that private initiative would produce in the absence of government intervention.

\section{CONCLUSION}

I have shown that the antiestablishment and antidiscrimination principles in school aid cases are both ultimately concerned with preventing the government from causing improper effects by giving financial assistance to private institutions. The agencies and courts implementing Title IX have developed elaborate and fairly consistent rules for determining how and when such effects occur. Perhaps it should not be surprising that those effects rules work in nearly the same way when applied to the problem of parochial school aid. But it is reassuring, in a way, that the Supreme Courtacting in an ad hoc fashion over a period of nearly 40 years- has worked out an architecture for the Establishment Clause that matches up so well, point for point, with a statutory and regulatory system designed as a coherent whole.

The only anomaly in the two systems is the Court's willingness to stretch the "program or activity" rule to cover entire institutions (or at least their educational functions) in primary and secondary religious school cases. In doing so, the Court credits theories of causation that it rejects under Title IX, and it does so without any evidence that they are more plausible in the Establishment Clause context. Its reasons for adopting those theories is the entanglement rule-itself a collection of hypotheses about causation that is even less supportable than the "program or activity" theories. Abandoning those hypotheses would bring the effects rules into line with Title IX law and would straighten out the major kink in Establishment Clause law.

${ }^{151}$ See, e.g., Thomas v. Review Bd., 450 U.S. 707 (1981); Sherbert v. Verner, 374 U.S. 398 (1963); Garvey, Freedom and Equality in the Religion Clauses, 1981 Supreme Court Review 193. 